\title{
Neoliberalism and Academia in Communication and Media Studies: A New Institutional Framework
}

\author{
Ángel Carrasco-Campos* and Enric Saperas**
}

*Department of Sociology, University of Valladolid, Segovia Campus, Group of Advanced Studies in Communication, Segovia, Spain, angel.carrasco.campos@uva.es, www.geac.es

${ }^{* *}$ King Juan Carlos University, Fuenlabrada Campus, Group of Advanced Studies in Communication, Madrid, Spain, enric.saperas@urjc.es, www.geac.es

\begin{abstract}
The disciplinary field of communication refers to a changing object of study, whose material delimitation depends on the political, socioeconomic and technological contexts in which it develops. These factors must be considered as structural elements, as they determine the knowledge demands and agenda of academia. This article aims to describe the keys to understanding the influence of neoliberalism as an ideology and structure in the academic institutionalisation of the field of communication. The analysis will take into special consideration the institutional dimension of research activity as a determining factor to understand the standards that define the dominant paradigm in neoliberal academia. These standards are shared by professionals in relation to working routines, research methodologies, objects of study, theoretical procedures, academic contexts, and dominant traditions, as well as strategies for the development of professional careers.
\end{abstract}

Keywords: neoliberal university, dominant paradigm, peer-reviewed journals, scholarly associations, university rankings

\section{Introduction}

Neoliberalism must be considered a mass deception (Ozgun 2011). Since the 1980s and 1990s, neoliberalism has promised a historic change conveyed by brand-new economic policies and a global capitalism that would inevitably unite the world in the scenario that followed World War II and the Cold War. However, almost thirty years after Francis Fukuyama (1992) proclaimed the End of History, this new social contract, which was instituted with no alternative, has not brought this promised prosperity. It has not created a Global Village fostered by a global market, nor ended class conflict, nor negated the gap between rich and poor. Neoliberalism has forgotten its pledge and has been developed into different forms. These include "cognitive capitalism" (Vercellone 2005; 2007; Moulier-Boutang 2011), "knowledge capitalism" (Olsen and Peters 2007) and "informational capitalism" (Castells 2000). Despite their differences (Fuchs 2011), these all refer to a global capitalism based on media communications, technology services, and cultural and creative industries that represent, for the first time, a new hegemonic economic model that embraces international political and ideological diversities: liberal democracies, social democracies, illiberal democracies, authoritarian regimes, autocracies, dictatorships, conservative populisms, nationalist populisms, and left-wing populisms. This economic and ideological model of globalisation has affected every extent of social, material and intellectual life, including a new institutional order for academia in times of global neoliberalism. 
Since the late 1980s, and especially during the 1990 s and early 2000 s, academic institutions, and public administrations and private corporations in charge of higher education and research, have undergone several transformations. These changes have converged in the creation of an institutional order that fits the productive system and the cultural archetype of neoliberalism, placing neoliberal academia in a prominent position among other essential reproductive structures. Europe, particularly the European Union (EU), must be considered the geopolitical environment in which the institutional framework of neoliberal academia has achieved the highest level of sophistication. The current scenario of the European Higher Education Area (EHEA) is the result of the neoliberal prototype adopted by the EU during the nineties, parallel to other social, legal and economic policies that marked a turning point in the objectives and standards developed over the previous decades. The EHEA is the culmination of a hegemonic model of academic globalisation that strives to build a universal and standardised dominant paradigm of research and teaching practices adjusted to the social contract of global capitalism. This institutional project, possibly the most successful across Europe, has determined not only the professional cultures of university teachers and researchers, but also the knowledge demands of public, private, individual, and institutional stakeholders. Even though there are differences between national university systems, there has typically been convergence with the American model. The United Kingdom rapidly adopted this model, followed by other Western European and Scandinavian university systems. Mediterranean and Central European countries have also adopted this model. Therefore, shared standards for academic activity have been developed across national university systems, forming a new model of normal science (Kuhn 1962) as a dominant paradigm of procedures and beliefs with a universalising scope for the scientific community.

This article identifies and analyses the institutions configuring the new framework emerging in neoliberal academia. It focuses on communication research as a case study, as this field can be paradigmatic of the social sciences as a whole. Economic, technological, and media globalisation have provided a space to consolidate the 'marketplace of ideas' in the field of communication. The world scenario during the nineties and the early 2000s is a key component to understanding contemporary communication and media research. The global situation in this time period created the potential for the emergence of global communicative phenomena and of cross-cultural uses of the media, which constitute emerging and strategic objects of study for the Information Society shared by the international academic community in their teaching and research agendas.

In the 20th century and the first decades of the new millennium, communication research has been one of the most dynamic and strategic factors in the development of political and economic systems. It has played a determinant role in the cultural cohesion of nations, the ideological dispute during the Cold War, and widespread cultural and economic globalisation over the past decades. For these reasons, even though the disciplinary field of communication is relatively new, its strategic role has rapidly surpassed academia itself by attending to the knowledge, interests, and demands of political and economic forces, as well as to the emancipation of audiences. According to Calhoun, this central position of communication research must be claimed today because

This field literally studies ways in which the world is made [...]. Communication is of central importance. Happily, many of the issues studied by the field of com- 
munication research are not only important but also increasingly widely recognized as important. Changes in patterns and media of communication are more and more clearly key dimensions of global change $(2011,1495)$.

Focusing on the disciplinary field of communication allows for a detailed description of the construction and operationalisation of a new form of a dominant paradigm (Gitlin 1978), or more accurately the reorganisation and update of the institutional paradigm defined by Elihu Katz (1987), which is rooted in the administrative research outlined by Paul F. Lazarsfeld (1941).

\section{Keys to Understanding Neoliberal Academia}

Global neoliberalism influences contemporary social structures (including academic structures), and therefore must be considered as more than just a historic development of power relationships. From the perspective of dialectical materialism, neoliberalism is more than just a contextual variable for understanding contemporary academic activity, it is also a constitutive element. If "it is not the consciousness of men that determines their existence, but, on the contrary, their social existence [that] determines their consciousness" (Marx 1904, 11-12), neoliberalism must be analysed as a structural and ideological element that defines the institutional framework of academia and its professional practices. Regarding communication research and the scope of the field, emphasis must be placed on political, economic, intellectual, and technological backgrounds, as they define the cross-disciplinary compositions and working routines of its academic community, establish knowledge interests and research and education agendas, set the reputation canons and professional ambitions of scholars, and create academic policies and quality standards (among other considerations). Consequently, the study of the academic institutionalisation of communication research involves analysing the contexts in which this process has occurred.

The analysis must begin in 1989, as this year represents the start of a radical global change after World War II. The fall of the Berlin Wall and the origin of the World Wide Web are two milestones that demonstrate the rise of global neoliberalism and its influence on media and communication studies. As noted in previous research (CarrascoCampos 2019; Saperas 2018; Carrasco-Campos and Saperas 2013; 2014; 2016), the 1990 s represent the consolidation of global neoliberal media, cultural and economic policies that were progressively implemented in national and international markets, labour conditions, social policies, education systems, cultural identities, science and technology and, of course, media systems. This diagnosis is shared across the political spectrum. For example, right-wing theorist Francis Fukuyama $(1989,3)$ declared "the total exhaustion of viable systematic alternatives to Western liberalism". Similarly, leftwing intellectual David Harvey remarked on the influence of neoliberalism in both a structural and an ideological dimension:

Neoliberalism is in the first instance a theory of political economic practices that proposes that human well-being can best be advanced by literally individual entrepreneurial freedoms and skills within an institutional framework characterized by strong private property rights, free markets, and free trade. The role of the state is to create and preserve an institutional framework appropriate to such practices [...]. Neoliberalism has, in short, become hegemonic as a mode of discourse. It has pervasive effects on ways of thought to the point where it has become incorporated into the common-sense way many of us interpret, live in, and understand the world $(2005,2-3)$. 
According to Milton Friedman (1951/2017), the roots of neoliberalism can be traced back to 19th-century liberalism, which focused on the importance of the individual, but substituted the laissez-faire for individual competition in the private sphere and used the state and public institutions to set the conditions for this competition. The 1980s stiffened these characteristics by consolidating state economic and cultural policies that rapidly became international, firstly among the most influential western countries controlling economic power, political influence, and technological innovation. This idea connects with current global neoliberalism in the post-Cold War world, which organises international relations between corporations and nations (independently of the domestic ideological structures developed behind borders), so that neoliberalism can be defined as a global order positioning the individual against society in a world competency scenario that mobilises any kind of institution, public or private, to configure, raise, and preserve it (Harvey 2005; Raimondi 2012). In fact, recent events such as the ongoing COVID-19 global pandemic may reinforce the global neoliberal ideology of competition, as there currently exists a global race to find a commercial formula for vaccination, a struggle for the acquisition of health resources, and a financial dispute in an acute crisis context.

Political, economic, cultural, and technological frameworks define and shape the knowledge demands and agendas of academic activity. For this reason, it is necessary to claim the role of neoliberalism as a structural factor in the development of social sciences and their institutions. Contrary to the dominant theories of positivism and structural functionalism that consider contextual elements only as an analytical variable to observe social phenomena, it is also crucial to account for the structural influence and ideological scope of neoliberalism. Hence, the purpose of contextualising the institutional framework of the field of communication must include an analysis of cultural and technological change, as well as political and economic backgrounds.

The Internet age and the post-Soviet world have led to new global social and economic structures that have radically transformed earlier media and cultural models. During the nineties, the North American media system achieved the hegemony expected after World War II, as the collapse of the Soviet Union symbolised both the fall of the political and economic system in conflict with capitalism and the cultural and symbolic archetype alternative to American media industries and consumer society. This supremacy facilitated contemporary standardisation of media content and formats by consolidating the audio-visual culture in a global consumer society, operating as an update to the modern myths described by Edgar Morin in reference to the star system (1960) and mass culture (1962). The audio-visual culture was fostered by the development of Internet communication, but under a multi-media structure promoting more interactive and customisable media consumption. Therefore, the globalisation of communication flows has not been threatened by emerging powers. On the contrary, the alleged multilateralism in economic and political spheres has not been translated into a multipolarity of media systems and cultural and creative industries beyond the dissemination of different lifestyles into pseudo-culture logic (Adorno 1993). The nineties witnessed the gradual alliance between media, culture, industry, and consumption anticipated by Max Horkheimer and T. W. Adorno (2002), and even by Dwight MacDonald (1960), in which an apparent diversity conceals the underlying homogeneity of the Masscult or the American PopCult. In short, the strongest component of the hegemonic North American cultural archetype is the communication system (Carrasco-Campos and Saperas 2011; 2012). 
The nineties also spurred a progressive convergence between different media businesses such as broadcasting, telecommunication operators, and knowledge industries, combining practices from financial capitalism and creative industries. Media communications, as a service used by multinational companies, are developed as a consumer good gathered from various personal devices, such as personal computers or smartphones. This transformation and convergence of media systems in neoliberal economies has put the media industries at the centre of socialisation. A hegemonic and one-dimensional (Marcuse 1964) culture model has been established in terms of a liquid consumer society (Bauman 2007), but is hidden by a supposed and apparent diversity that facilitates the personalisation of media experiences and devices. The essential mutation of communication processes occurred when technological innovation ceased to be only external to individuals (consumption of television, fiction, entertainment, advertising, reading the press, etc.) and became part of their social relationships. A combination of an imaginary diversity of communicative uses and interactions has occurred in the common context of neoliberal trans-nationalisation, in which "the communication industry has become one of the largest industries in the global deal markets as a result of vertical and horizontal integration" (Jin 2008, 357). Thus, the globalisation of the communication market has formed an international framework aimed at standardising markets, in which digital technology has been an essential driving force.

\section{The Contemporary Institutional Framework of Media and Communication Research}

As a correlate to the change in international context, a relevant shift also occurred in the 1990s regarding the organisation of the disciplinary field. New actors focused the methodological debate and strived to create a meta-discourse that defined the discipline, established the methods and variants of the theoretical construction considered valid and useful for generating knowledge, and proceeded to institutionalise a paradigm with an international vocation. Thus, the research activity in neoliberal academia is currently defined by three institutional modalities:

1. The publishing industry, bibliographical databases, and citation indexes: Besides their traditional function in the dissemination of knowledge, these institutional agents have assumed new duties related to the promotion of research interests and standards. The analysis will focus on peer-reviewed journals, abstracts and citation databases, and the mainstream publishing industry.

2. International academic associations: As in the previous case, this institution has always existed in contemporary social sciences. However, it has recently developed a new hegemonic function regarding the definition of the field and the designation of research agendas and routines.

3. Institutions for the evaluation of research activity and reputation: This recent modality is closely linked to neoliberal academia and includes institutions such as international academic rankings and university rating agencies.

Globalisation informed by neoliberal policies has shaped the institutional frameworks on which the academic profession develops. Nevertheless, it is important to note that we will not analyse the traditional labour conditions of neoliberal universities, which have been studied (with empirical evidence in most cases) in previous research that stresses the new models' surveillance and subjectivities in academia (Allmer 2012; Gill 2013), precarious employment (Luka et al. 2016; Gill 2017; Allmer 2018), and psychological anxiety (Berg, Huijbens and Larsen 2016). 


\subsection{The Mainstream Publishing Industry, Bibliographical Databases, and Citation Indexes}

Although the publishing industry has long existed within modern social sciences, the current dominant institutional framework has been actively re-shaped by the new role developed by peer-reviewed journals, which are currently the most significant reference for the international academic community. Despite the fact that academic journals are mainly located in the Anglo-American sphere, their influence has become global.

The COVID-19 crisis has shown the radical contemporary influence of peer-reviewed journals in science and society. Since the first stages of the pandemic, the COVID-19 crisis has become an emerging object of study in the field of communication. There is a growing demand for research on this topic, demonstrated by special calls for papers, and scholars have detected several urgent communication problems, such as crisis and risk communication, infodemics and fake news, media uses and consumption, and so on. Although this situation has contributed to improved knowledge about the pandemic's implications on social life, information, and communications, it has also motivated many scholars to temporarily abandon their main research lines to focus on such topics, as this research niche is very profitable in curricular terms. Furthermore, the dominance of peer-reviewed journals is present in other disciplines, including bio-medicine, pharmacology, and other health sciences. Although they are not the object of this article, these fields also report how academic journals set the pace of research dissemination, accommodating peer-reviewed criteria, pre-print editions, and special issues in a global competition for social and academic reputation.

Additionally, academic journals have overtaken the position that was previously occupied by textbooks and monographies in the definition and delimitation of the field, which includes theoretical debate and, most importantly, the standardisation of methodological procedures. The role played by large commercial editorial companies is still important, but this industry has essentially re-oriented production from the classical monographies that were used as reference textbooks for academic education to collections of book chapters, usually in multi-authorship format. These collections are similar to peer-reviewed journals in many ways, including in writing standards and the submission to peer-reviewed criteria.

Over the past decades, peer-reviewed journals have conveyed important debates in the field, as they have combined theoretical and methodological debates and have set the agenda for strategic objects of study. The publication of specialised journals and the calls for thematic special issues have also promoted the development of the state of the art and the build-up of a critical mass in any topic. A journal first played this role in communication studies in 1983, when the flagship journal of the International Communication Association (ICA) edited the special issue Ferment in the Field (Gerbner and Siefert 1983) to face "questions about the role of communications scholars and researchers, and of the discipline as a whole, in society" (Gerbner 1983, 4). Ten years later, although less impactful, a new edition of Ferment in the Field entitled The Disciplinary Status of Communication Research (Levy and Gurevitch 1993) would take over; and again, in 2018, the special issue Ferments in the Field: The Past, Present and Future of Communication Studies (Fuchs and Qiu 2018) was released. Despite their distinctions, these special issues have embraced the diversity of communication by defining it as a multidisciplinary field and avoiding the theoretical and methodological dispute, thereby characterising the different research interests as representing "a wide diversity of research traditions and scholarly aspirations" of the "extraordinary 
pluralism of our field", although they may "have very different and sometimes competing ideas" (Fuchs and Qiu 2018, 220).

The growing influence of peer-reviewed journals has promoted the rise of other allied institutions: bibliographical databases and citation indexes, among which stand two private initiatives, WoS-JCR ${ }^{1}$ and Scopus-SJR. ${ }^{2}$ Both are based on the calculation of citations in aggregate annual periods and provide a statistical description of the impact of research by using the citation system to measure academic and professional reputation.

These institutional agents define the framework for academic production and dissemination and influence critical aspects of research activity. The agents affect the delimitation of the field, in which theoretical diversity is accepted only if these theories relate to recognisable objects of study and are operationalised within the margins of the methodological and procedural standards set by peer-review criteria shared by the scholarly system (Neuman et al. 2008). However, these criteria are not neutral, as they indirectly regulate what can be published and, as a consequence, what is worth researching from a professional dimension, and not necessarily for the social interest.

\subsection{International Academic Associations}

Since the 1990s, the institutional framework for communication studies has undergone a second transformation due to the dominance of associations of research professionals. Although they have always had a strong presence in every field, over the last forty years scholarly associations have developed a new function in promoting globalised academia. Now at the beginning of the 21 st century, they have achieved a full domain in international communication research: the broad spread of periodical business meetings has consolidated a previously lengthy process in the current demarcation of the field, its intellectual systematisation, the setting of the research agenda and scientific policies, and the creation of international networks. Additionally, the progressive internationalisation of these institutions has rapidly evolved by embracing scholars of different nationalities and research interests under the umbrella of common methodologies and objects of study.

The presence of international academic associations is decisive in many aspects of communication research, and they have implemented specific administrative procedures for the self-definition of the field through the taxonomy of thematic sections and working groups. Despite certain differences and internal regulations, this structure is replicated by most international and national associations. Sections of associations usually foster internal struggle in the methodological and theoretical aspects of research topics with a more numerous and consolidated critical mass, and working groups typically unify the emerging task forces and incipient objects of study, aiming to set the research agenda, and then to consolidate. Both sections and working groups promote the debate of the association while aspiring to achieve maximum representation and influence.

Three international associations currently exist that compete, and sometimes collaborate, for influence in the discipline of communication: the International Communication Association (ICA), the International Association for Media and Communication Research (IAMCR), and the European Communication Research and Education As-

\footnotetext{
${ }^{1}$ https://www.fecyt.es/es/recurso/web-science

2 https://www.scimagojr.com/
} 
sociation (ECREA), the latter having a European scope but striving toward global influence. The sections and working groups of these associations ${ }^{3}$ offer an overview of the objects of study that are considered relevant in the field of communication. A careful analysis of this effort to subdivide and organise research interests allows for recognition of the discipline of communication by its preferred objects of study. These three associations have effectively thematically classified and organised intellectual communication and media research. They also incorporate new strategic demands of knowledge that respond to a society in transformation and to the increasing hybridisation and transnationalisation of media systems in the context of cultural, political, economic, and technological globalisation. This task assumed by the international associations is generally developed by avoiding the political and economic agendas of research; that is, the imagined diversity of research interests is developed by setting aside any ideological and theoretical adscription that may cause internal fragmentation (this includes critical research into communication). However, according to Kaarle Nordenstreng it is possible to view the IAMCR's Political Economy as a remarkable and rare exception:

However, nowadays the IAMCR's activities, with all their diversity, hardly appear to be more critical than, for example, those of the European Communication Research and Education Association (ECREA). An exception is the Political Economy Section, which since the mid-1970s has provided support and stimulation for already two generations of critical scholars (2016, 89-90).

This precaution in avoiding political and ideological debates that concern communication does not make the associations a scenario for the integration of scholars regardless of relations of individual competition. Beyond their efforts to determine the research agendas and scientific policies developed by the thematic sections and working groups, scholarly associations work to improve professional reputations by participating in directive positions and keynote speeches and roundtables at periodical conferences. Doubtless, associations aim to stimulate academic debate, which might produce editorial initiatives, and to create collaborative networks for the promotion of international and comparative studies. As a consequence, they become responsible for setting the tone of formal and informal working routines and in-group leadership processes.

\subsection{Institutions for the Evaluation of Research Activity and Reputation}

This modality is composed by institutions developed under the neoliberal model, and it includes diverse public and private agents who specify the standards for the promotion, comparison, and competition of professional careers, and the reputation of scholars, universities, and research centres. This brand-new institutional ecosystem includes the evaluation and accreditation agencies of academic activity, the corporations responsible for the evaluation and creation of university rankings, the authorities that determine criteria for funded research, and the institutions that set the standards and measure the impacts of research, generally using statistical and bibliometric-grounded ranks.

These companies and institutions have best crystallised the economistic and globalised market values, as they are in charge of measuring the professional activity of

${ }^{3}$ ICA: https://www.icahdq.org/; IAMCR: https://iamcr.org/s-wg; ECREA: https://ecrea.eu/Sec$\underline{\text { tions }}$ 
scholars according to standardised criteria. In the form of rating agencies, they significantly influence public management of universities and R\&D\&I-funded projects, bibliometric studies, academic production and impact, accreditations of all kinds, reputation indexes, and so on. They are an absolute novelty of neoliberal academia, as they categorise professional careers, university and research centres, and an institution's academic capacity (Kandiko 2010; Levidow 2002) using criteria like the measures of economic and financial or commercial productivity. Similar to financial market rating agencies, these institutions provide a shared statistical and quantitative index to compare and compete for research funds, top ranks, and professional reputation. In fact, Kaarle Nordenstreng indicated in 2004 that "The universities in today's Europe show how higher education is being increasingly treated as a branch of the economy with performance targets and closer links to the industrial world and its professional life" (Nordenstreng 2004, 8).

Considering their novelty and function relating closely to neoliberal academia, the companies that design university rankings should be highlighted. Despite the fact that in some countries (such as Great Britain and North America ${ }^{4}$ ) such companies appeared during the 1980s and 1990s as public, private, or mixed systems of national scope for evaluating academic achievement standards, their current corporate and international version as a global business (Amsler and Bolsmann 2012) began in the early 2000s. The three most relevant cases are the Academic Ranking of World Universities (ARWU; best known as the Shanghai Ranking), the QS World University Rankings, and the Times Higher Education World University Rankings. These organisations have developed different evaluation criteria, ${ }^{5}$ which is an element of conflict between them (Hou and Jacob 2017). Nevertheless, all three agree on assigning some of the preeminent values to the citation indexes (WoS-JCR and Scopus-SJR), reputation surveys among scholars and employers, and, to a lesser extent, different criteria on the quality of teaching and the ability to attract students (best national academic records, excellent foreign students) and scholars.

University rankings have become commonplace in the evaluation of every field, as evidenced by the neoliberal logic of international competition that determines academic excellence through measurable standard variables that allow for comparison and competition for the top ranks. A broad dominant discourse, in both the academic and the public sphere, uses the data generated by these institutions as a mechanism to grant prestige to university and research centres. Thus, universities are identified by their position in international rankings created by rating agencies, which act similarly or identically to rating agencies in financial markets. A university's reputation and quality of research is placed into its index and measurement standards.

4 The national survey 'Best Colleges in the Country' published in 1983 by the US News \& World Report can be noted as a close forerunner to today's university rankings. In the United Kingdom, the rankings published by The Times (1992), The Sunday Times (1998), The Financial Times (1998), and The Guardian (1999), based on secondary school performance tables, are other relevant precedents.

5 QS World University Ranking: https://www.topuniversities.com/qs-world-university-rankings/methodology

THE World University Ranking: https://www.timeshighereducation.com/world-universityrankings/world-university-rankings-2020-methodology

ARWU-Shanghai Ranking: http://www.shanghairanking.com/ARWU-FIELD-Methodology2016.html 


\section{The Neoliberal Standardisation of the Social Sciences: The Institutional Framework of Media and Communication Research as the Dominant Paradigm in the Era of Globalisation}

\subsection{Historical Precedents of the Current Neoliberal Paradigm}

The previously described three components of the contemporary institutional framework of science situate communication and media research within neoliberal academia, as it promotes professional standards concerning working routines, theoretical and methodological procedures, strategic objects of study and criteria for the evaluation of academic activity. This framework describes the consolidation of the current paradigm of standard work in communication research. However, although the contemporary form of the standard work is distinct to the neoliberal context, the idea of having specific 'work standards' in communication research is not new. The prototypical figure of this research standardisation connects with previous concepts such as the "middle range theories" defined by Robert K. Merton (1949), the "administrative research" described by Paul F. Lazarsfeld (1941), and the recurrent idea of a dominant paradigm in communication research that can be traced from Everett M. Rogers (1976) to Elihu Katz (1987), as well as through Daniel Lerner and Wilbur Schramm (1967) and Todd Gitlin (1978).

Middle-range theory serves as a precedent to the idea that, in opposition to 'total systems', social research must be carried out through empirically confirmed working hypotheses. As Raymond Boudon (1991) ironically stated, this specific definition of 'theory' in sociology corresponds to the usual notion of 'theory' in the rest of the empirical and social sciences, where 'total systems' of theory are no longer considered. The definition also fits the concept of 'administrative research', as this is defined as the first form of applied research in communication with eminently practical purposes. Nevertheless, these concepts are both related to the notion of the 'dominant paradigm', which has always used administrative research as a reference for communication studies with a practical and applied orientation, meaning a model of standard empirical research that must be referential to the scholarly community because of its efficiency and applicability. In fact, this notion of 'theory' relates to the idea of 'traditional theory' defined by Max Horkheimer (2002) in opposition to Critical Theory, in the same way that middle-range theories are oppositional to total systems, and administrative research is explicitly contrary to Critical Communication Research.

Communication and media research has always been a contested terrain in sociological and epistemological terms. The debate regarding the uses of social research in communication studies and the role of the social scientist is a constitutive factor of the field. Although outside the scope of this article, a more detailed analysis may show that even the previous stages of the dominant paradigm of applied communication research, which was similar to structural functionalism, have been dialectically developed in confrontation with other frameworks and paradigms (Gitlin 1978; Craig 1999). Therefore, the presumed lineal development of a dominant paradigm in communication research through an empirical standard work involving high applicability and explicative capacity and supported by recognisable techniques and partial theories is an ideological simplification, as it has been established with greater or lesser hegemony in opposition to critical research (Critical Theory, Frankfurt School, Political Economy of Communication), socio-phenomenological research (symbolic interactionism, constructivism), and technological studies. Specifically regarding critical research, this dialectical dispute can be traced back to the controversy with administrative research during the 1930s (Adorno 1969; Lazarsfeld 1941; Supa 2009). It is also rooted in the positivism 
dispute in sociology (Adorno et al. 1976), and the balkanization of sociology during the 1960s, when different scholarly traditions such as the New Left, the Political Economy of Communication and the first generation of Cultural Studies arose, following the lead of the Frankfurt School but breaking with some of its core elements. Critical research is currently being widely claimed by scholars (Fuchs 2016; 2020; Fuchs and Mosco 2012; Nordenstreng 2016; Wasko 2018; Wasko, Murdock and Sousa 2011, among others) as it contends with the dominant paradigm as an alternative, especially in such topics as digital labour (Fuchs 2014), the transnationalisation of communication markets and cultural and creative industries (Jin 2008), digitalisation and big data (Chandler and Fuchs 2019) and the dominance of Internet-related services and products of large international companies and social media (Fuchs 2011; Han 2015; 2017).

\subsection{The Dominant Paradigm: A Universal Model of Standard Work in Communication and Media Research}

The dominant paradigm of the development of communication research involves the delineation of well-defined work standards for empirical procedures. These standards are developed by defining methodologically replicable designs, for which theoretical development is achieved by accumulating verifiable hypotheses leading to middlerange theories. However, although the current dominant paradigm of standard work shares features with previous stages (empirical applicability, explanatory potential, cumulative advance), it has other distinctive qualities. Perhaps what makes this new era of the dominant paradigm unique is its definitive hegemony with the contribution of the institutional framework described previously, fostered by the structural and ideological dimension of neoliberal academia. In contrast to previous stages of the dominant paradigm in communication research, the neoliberal spirit of individual competition ideologically influences academic activity.

The current changes represent a qualitative leap and, therefore, an irreversible paradigm shift. As previously argued, the editorial standards adopted by the publishing industry and academic journals, the influence of international academic associations, university rankings, competitive calls for scholarships and research projects, measurements of the impact and transfer of research results, the processes of international confluence of Higher Education, and the evaluation and accreditation of researchers and university professors have provided an institutional framework for communication research whose processes and dynamics must be considered in their specific context. The institutional framework for research provides specific criteria for the evaluation, assessment and comparison of professional careers and the academic status and reputation of scholars and research centres that operate globally in a shape very close to neoliberal financial markets. Thus, it seems that neoliberal academia tends toward four different criteria for the global standardisation of communication and media research regarding theoretical and methodological procedures, research topics, and the dissemination and impact of results.

Firstly, the focus on the objects of study provides definition and structure to the field. As described earlier, this function was developed by its own delimitation and systematisation carried out by the international academic community through the sections and working groups of the research associations. Simultaneously, this systematisation is explicitly included in the elaboration of the curricula and study plans for university degrees, as well as the research agendas and academic policies, all of which establish strategic and emerging study objects. For this reason, it is common to appeal to topics and phenomena that have previously been standardised, such as cultural and media consumption, media systems, and professional routines. This allows researchers to 
avoid political and theoretical adscriptions, causing a significant loss in the value of theory in communication research. Contemporary dominant theorising is frequently related to instrumental functions, such as the organisation of the field, the formulation of hypotheses for empirical advance by replication and refutation, and the inductive generalisation of results.

The second criterion is the rise of comparative studies, as it seems that this current trend is possible only when considering both the economic, technological, and cultural globalisation and convergence that provide global phenomena to compare and also the methodological standards shared by a global academic community creating common procedures and criteria for development. Driven by political, economic, and media globalisation, this type of research forms one of the most outstanding elements of contemporary scientific agendas and policies, and not only in communication research. The identification and operationalisation of variables and indicators to measure and observe media systems and professional communication cultures are emerging challenges for the alliance between economy, society, and academia (as a new shape of administrative research and its typical ethic of cooperation). Journalism research and the study of media systems stand out, but with a significant impetus, this type of research also appears in strategic communication, the uses and consumption of social media, and even in comparative analysis of the cultural industries through the so-called creative and knowledge industries. This implies the predominance of empirical and statistical research models with high replication capacity but weak uses of theory. Replicability and applicability, typical of standard work, become essential requirements for this type of strategic study for political, economic, and media globalisation.

Thirdly, standardisation processes also affect the procedures of measuring and evaluating research. This measurement generally occurs through statistical criteria that allow rapid comparison and ranking of the evaluated items, including the productivity and impact of academic and teaching performance, and the professional reputation of researchers and institutions. This aspect represents the most intimate connection between neoliberalism and academia, as it presents the scope of market criteria in measuring the profitability of the social sciences. One of the main consequences of these standards lies in the very concept of excellence and academic reputation, which is resolved in a list of algorithms for each field. These formulas are used to validate professional performance, the impact of academia, and the transfer of knowledge (among other factors) and aim to guide the supply and demand of jobs; human, economic and material resources; and future students.

The final criterion is the academic culture of 'publish or perish' (Coolidge and Howard 1932; Garfield 1996). Even though the dissemination of results and methodological procedures is an inalienable part of all academic activity, in neoliberal academia publication becomes almost an end in itself. This is largely due to the standards of measurement and comparison, including impact factors and citations (mainly JCR-WoS and SJR-Scopus) that create an eminently individual struggle for professional reputation and development. This leads research professionals to seek curricular, but not necessarily social, profitability for their activity. Because of this work ethic, publication (preferably in top-rank peer-reviewed journals) and integration into international academic networks become priority objectives for research professionals. Thus, academic journals and peer-reviewed criteria become allied with citation indexes as gatekeepers of research activity. These institutions set the dominant theoretical frameworks (in the form of middle-range theory), the valid methodological procedures (mainly comparative, replicative, and cumulative), and the strategic objects of study. Therefore, the 
emancipatory knowledge interests (Habermas 1972) typical to critical research are often professionally marginalised by being excluded from these research agendas.

In this regard, the ideology of neoliberalism is present in all the previously described elements that conform to the current institutional framework of research activity. $\mathrm{Ne}$ oliberalism emphasises the logic of global competence by setting standards for the comparison of individuals in a common context. Therefore, the institutional framework adopted by neoliberal academia can be considered a gatekeeper of research activity, as it promotes a hegemonic model of standard work. This model is neither unique nor universal, nor an explicitly forced standard to adopt, but functions as an archetypical delimitation of the profession.

\section{References}

Adorno, Theodor W. 1993. Theory of Pseudo-Culture (1959). Telos 95: 15-38.

Adorno, Theodor W. 1969. Scientific Experiences of a European Scholar in America. In The Intellectual Migration. Europe and America, 1930-1960, edited by Donald Fleming and Bernard Bailyn, 338-370. Cambridge, MA: Harvard University Press. Accessed August 9, 2020. https://doi.org/10.4159/harvard.9780674334120

Adorno, Theodor W., Hans Albert, Ralf Dahrendorf, Jürgen Habermas, Harald Pilor, and Karl R. Popper. 1976. The Positivist Dispute in German Sociology. London: Heinemann.

Allmer, Thomas. 2018. Precarious, Always-on and Flexible: A Case Study of Academics as Information Workers. European Journal of Communication 33 (4): 381-395.

Allmer, Thomas. 2012. Towards a Critical Theory of Surveillance in Informational Capitalism. Frankfurt am Main: Peter Lang.

Amsler, Sarah S. and Chris Bolsmann. 2012. University Ranking as Social Exclusion. British Journal of Sociology of Education 33 (2): 283-301.

Bauman, Zygmunt. 2007. Consuming Life. Oxford: Polity Press.

Berg, Lawrence D., Edward H. Huijbens and Henrik Gutzon Larsen. 2016. Producing Anxiety in the Neoliberal University. The Canadian Geographer / Le Géographe canadien 60: 168180.

Boudon, Raymond. 1991. What Middle-Range Theories Are. Contemporary Sociology 20 (4): 519-522. https://doi.org/10.2307/2071781

Calhoun, Craig. 2011. Communication as Social Science (and More). International Journal of Communication 5: 1479-1496.

Carrasco-Campos, Ángel. 2019. Consideraciones Epistemológicas Sobre los Usos de la Teoría en la Investigación Comunicativa Actual. In Epistemología de la Comunicación y Cultura Digital: Retos Emergentes, edited by Francisco Sierra and Jordi Alberich, 231242. Granada: EUG. Accessed September 14, 2020. https://dialnet.unirioja.es/servlet/articulo? codigo $=7165055$

Carrasco-Campos, Ángel and Enric Saperas. 2016. Cambio Tecnológico, Globalización Neoliberal y Hegemonías Metodológicas en la Investigación Comunicativa Internacional. Ámbitos 32. Accessed September 14, 2020. https://institucionales.us.es/ambitos/cambiotecnologico-globalizacion-neoliberal-y-hegemonias-metodologicas-en-la-investigacion-comunicativa-internacional/

Carrasco-Campos, Ángel and Enric Saperas. 2014. Debate, Confrontación y Hegemonía en la Disciplina de la Comunicación. Nuevos Tiempos para un Paradigma Dominante. Redes.com 10: 145-158. Accessed September 14, 2020. https://dialnet.unirioja.es/servlet/articulo?codigo $=5012384$

Carrasco-Campos, Ángel and Enric Saperas. 2013. Las Teorías de la Comunicación Hoy: Contexto Histórico, Cambios Tecnológicos y Nuevo Estatuto Epistemológico de la Investigación Comunicativa. In Actas del II Congreso Nacional sobre Metodología de la Investigación en Comunicación y del Simposio Internacional sobre Política Científica, edited by Miguel Vicente-Mariño, Tecla González-Hortigüela and Marta Pacheco-Rueda, 959-968. 
Segovia: Facultad de SJC. Accessed September 14, 2020. https://dialnet.unirioja.es/servlet/articulo?codigo $=4230485$

Carrasco-Campos, Ángel and Enric Saperas. 2012. La Unesco y la Institucionalización de la Cultura: Hacia un Nuevo Estatuto de la Cultura. Razón y Palabra 80. Accessed September 14, 2020. http://www.razonypalabra.org.mx/N/N80/M80/09 CarrascoSaperas M80.pdf

Carrasco-Campos, Ángel and Enric Saperas. 2011. La Institucionalización del Concepto de Industrias Culturales en el Proceso de Debate Sobre Políticas Culturales en la Unesco y el Consejo de Europa (1970- 1982). adComunica 2: 143-158. Accessed September 14, 2020. http://www.adcomunicarevista.com/ojs/index.php/adcomunica/article/view/33

Castells, Manuel. 2000. The Rise of the Network Society. The Information Age: Economy, Society and Culture. Volume 1. Malden: Blackwell.

Chandler, David and Christian Fuchs, eds. 2019. Digital Objects, Digital Subjects: Interdisciplinary Perspectives on Capitalism, Labour and Politics in the Age of Big Data. London: University of Westminster Press. Accessed August 31, 2020. https://www.uwestminsterpress.co.uk/site/books/e/10.16997/book29/

Coolidge, Harold Jefferson and Robert Howard. 1932. Archibald Cary Coolidge: Life and Letters. New York: Books for Libraries Press.

Craig, Robert T. 1999. Communication Theory as a Field. Communication Theory 9 (2): 119161.

Friedman, Milton. 1951/2017. Neo-Liberalism and its Prospects. Framnad 17 February 1951: 89-93. Accessed August 31, 2020. https://miltonfriedman.hoover.org/friedman images/Collections/2016c21/Farmand 0217 1951.pdf

Fuchs, Christian. 2020. Communication and Capitalism: A Critical Theory. London: University of Westminster Press. Accessed August 31, 2020. https://library.oapen.org/handle/20.500.12657/39717

Fuchs, Christian. 2016. Critical Theory of Communication: New Readings of Lukács, Adorno, Marcuse, Honneth and Habermas in the Age of the Internet. London: University of Westminster Press. Accessed August 31, 2020. https://www.uwestminsterpress.co.uk/site/books/m/10.16997/book1/

Fuchs, Christian. 2014. Digital Labour and Karl Marx. New York: Routledge.

Fuchs, Christian. 2011. Cognitive Capitalism or Informational Capitalism? The Role of Class in the Information Economy. In Cognitive Capitalism, Education and Digital Labor, edited by Michael Peters and Ergin Bulut, 75-119. New York: Peter Lang. Accessed August 25, 2020. http://fuchs.uti.at/wp-content/uploads/cognitivecapitalism.pdf

Fuchs, Christian and Vincent Mosco. 2012. Introduction: Marx is Back - The Importance of Marxist Theory and Research for Critical Communication Studies Today. tripleC: Communication, Capitalism \& Critique 10 (2): 127. Accessed August 31, 2020. https://www.triplec.at/index.php/tripleC/article/view/421

Fuchs, Christian and Jack L. Qiu. 2018. Ferments in the Field: Introductory Reflections on the Past, Present and Future of Communication Studies. Journal of Communication 68 (2): 219-232.

Fukuyama, Francis. 1989. The End of History? The National Interest 16: 3-18.

Fukuyama, Francis. 1992. The End of History and the Last Man. New York: The Free Press.

Garfield, Eugene. 1996. What Is The Primordial Reference For The Phrase 'Publish Or Perish'? The Scientist 10 (12): 10-13. Accessed June 18, 2020. https://www.the-scientist.com/commentary/what-is-the-primordial-reference-for-the-phrase-publish-or-perish$\underline{57976}$

Gerbner, George. 1983. Introduction. Journal of Communication 33 (3): 4-5.

Gerbner, George and Marsha Siefert, eds. 1983. Ferment in the Field: Communication Scholars Address Critical Issues and Research Tasks of the Discipline. Journal of Communication 33 (3). 
Gill, Rosalind. 2017. Beyond Individualism: the Psychosocial Life of the Neoliberal Univesrity. In A Critical Guide to Higher Education \& the Politics of Evidence: Resisting Colonialism, Neoliberalism \& Audit Culture, edited by Marc Spooner. Regina (Canada): University of Regina Press.

Gill, Rosalind. 2013. Academics, Cultural Workers and Critical Labour Studies. Journal of Cultural Economy 7 (1): 12-30.

Gitlin, Todd. 1978. Media Sociology: The Dominant Paradigm. Theory and Society 6 (2): 205-253.

Habermas, Jürgen. 1972. Knowledge and Human Interests. London: Heinemann Educational.

Han, Byung-Chul. 2017. Psychopolitics: Neoliberalism and New Technologies of Power. New York: Verso Books.

Han, Byung-Chul. 2015. The Transparency Society. Stanford: Stanford Briefs.

Harvey, David. 2005. A Brief History of Neoliberalism. Oxford: Oxford University Press.

Horkheimer, Max. 2002. Traditional and Critical Theory. In Critical Theories: Selected Essays, 188-244. New York: Continuum.

Horkheimer, Max and Theodor W. Adorno. 2002. Dialectic of Enlightment: Philosophical Fragments. Stanford: Stanford University Press.

Hou, Ya-Wen and W. James Jacob. 2017. What Contributes More to the Ranking of Higher Education Institutions? A Comparison of Three World University Rankings. The International Education Journal: Comparative Perspectives 16 (4): 29-46. Accessed June 18, 2020. https://openjournals. library.sydney.edu.au/index.php/IEJ/article/view/10638

Jin, Dal Yong. 2008. Neoliberal Restructuring of the Global Communication System: Mergers and Acquisitions. Media, Culture and Society 30 (3): 357-373.

Kandiko, Camille B. 2010. Neoliberalism in Higher Education: A Comparative Approach. International Journal of Arts and Sciences 3 (14): 153-175. Accessed June 18, 2020. http://www.openaccesslibrary.org/images/BGS220 Camille B. Kandiko.pdf

Katz, Elihu. 1987. Communicaton Research Since Lazarsfeld. Public Opinion Quarterly 51: 25-45.

Kuhn, Thomas S. 1962. The Structure of Scientific Revolutions. Chicago: University of Chicago Press.

Lazarsfeld, Paul Felix. 1941. Remarks on Administrative and Critical Communication Research. Studies in Philosophy and Social Science 9: 2-16. Accessed June 20, 2020. https://aphelis.net/wp-content/uploads/2012/06/Lazarsfeld 1941 admin critical communication.pdf

Lerner, Daniel D. and Wilbur Schramm. 1967. Communication and Change in the Developing Countries. Honolulu: University Press of Hawaii.

Levidow, Les. 2002. Marketizing Higher Education: Neoliberal Strategies and Counter-Strategies. In The Virtual University? Knowledge, Markets and Management, edited by Kevin Robins and Frank Webster, 227-248. Oxford: Oxford University Press. Accessed June 18, 2020. http://oro.open.ac.uk/5069/

Levy, Mark R. and Michael Gurevitch, eds. 1993. The Disciplinary Status of Communication Research. Journal of Communication 43 (3).

Luka, Mary-Elizabeth, Alison Harvey, Mél Hogan, Tamara Shepherd and Andrea Zeffiro. 2016. Scholarship as Cultural Production in the Neoliberal University: Working Within and Against 'Deliverables'. Studies in Social Justice 9 (2): 176-196. Accessed June 18, 2020. https://journals.library.brocku.ca/index.php/SSJ/article/view/1138

MacDonald, Dwight. 1960. Masscult and Midcult. The Partisan Review 27 (4).

Marcuse, Herbert. 1964. One Dimensional Man. Boston: Beacon Press.

Marx, Karl. 1904. A Contribution to the Critique of Political Economy. New York: The International Library Publishing.

Merton, Robert K. 1949. Social Theory and Social Structure. New York: The Free Press. (revised and expanded in 1957 and 1968). 
Morin, Edgar. 1962. L'espirit du Temps. Essai sur la Culture de Masse. Paris: Grasset.

Morin, Edgar. 1960. The Stars. An Account of the Star System in Motion Pictures. New York: Gorve Press.

Moulier-Boutang, Yann. 2011. Cognitive Capitalism. Cambridge: Polity Press.

Neuman, W. Russell, Roei Davidson, Sung-Hee Joo, Yong Jin Park, and Ann E. Williams. 2008. The Seven Deadly Sins of Communication Research. Journal of Communication 58 (2): 220-237.

Nordenstreng, Kaarle. 2016. Being (Truly) Critical in Media and Communication Studies: Reflections of a Media Scholar Between Science and Politics. Javnost - The Public 23 (1): 89-104.

Nordenstreng, Kaarle. 2004. Ferment in the Field: Notes on the Evolution of Communication Studies and its Disciplinary Nature. Javnost - The Public 11 (3): 5-17.

Olsen, Mark and Michael A. Peters. 2007. Neoliberalism, Higher Education and the Knowledge Economy: From the Free Market to Knowledge Capitalism. Journal of Education Policy 20 (3): 313-345.

Ozgun, Aras. 2011. Creative Industries: Neo-Liberalism as Mass Deception. In Culture and Contestation in the New Century, edited by Marc James Léger, 105-124. Bristol: Intellect Ltd. Accessed June 18, 2020. http://arasozgun.net/Aras Ozgun-Creative Industries.pdf

Raimondi, Linda. 2012. Neoliberalism and the Role of the University. PAACE Journal of Lifelong Learning 21: 39-50. Accessed June 15, 2020. https://url2.cl/bcGG4

Rogers, Everett M. 1976. Communication and Development. The Passing of the Dominant Paradigm. In Communication and Development. Critical Perspectives, edited by Everett M. Rogers, 121-148. Beverly Hills/London: Sage Publications.

Saperas, Enric. 2018. La Investigación Comunicativa en España en Tiempos de Globalización. La Influencia del Contexto Académico y de Investigación Internacionales en la Evolución de los Estudios sobre Medios en España. In Investigar en la Era Neoliberal. Visiones Críticas Sobre la Investigación en Comunicación en España, edited by Aarón Rodríguez and Samuel Gil, 207-226. Barcelona/Castellón/Valencia: Aldea Global.

Supa, Dustin W. 2009. The Origins of Empirical Versus Critical Epistemology in American Communication. American Communication Journal 11 (3). Accessed August 9, 2020. http://ac-journal.org/journal/2009/Fall/4TheOriginsofEmpirical.pdf

Vercellone, Carlo. 2007. From Formal Subsumption to General Intellect: Elements for a Marxist Reading on the Theses of Cognitive Capitalism. Historical materialism 15 (1): 1336. Accessed June 18, 2020. https://halshs.archives-ouvertes.fr/halshs-00263661/document

Vercellone, Carlo. 2005. The Hypothesis of Cognitive Capitalism. Towards a Cosmopolitan Marxism, Historical Materialism Annual Conference. Birkbeck College and SOAS, London, 4-6 November. Accessed June 18, 2020. https://halshs.archives-ouvertes.fr/file/index/docid/273641/filename/The hypothesis of Cognitive Capitalismhall.pdf

Wasko, Janet. 2018. Studying Political Economies of Communication in the Twenty-First Century. Javnost - The Public 25 (1-2): 233-239. Accessed August 31, 2020. https://wwwtandfonline-com.bucm.idm.oclc.org/doi/pdf/10.1080/13183222.2018.1424031

Wasko, Janet, Graham Murdock, and Helena Sousa. 2011. Introduction: The Political Economy of Communications: Core Concerns and Issues. In The Handbook of Political Economy of Communications, edited by Janet Wasko, Graham Murdock and Helena Sousa, 110. Oxford: Wiley-Blackwell. Accessed August 25, 2020. https://onlinelibrary.wiley.com/doi/pdf/10.1002/9781444395402.ch 


\section{About the Authors}

Ángel Carrasco-Campos

Associate professor of the Department of Sociology at the University of Valladolid (Spain), researcher at the Group of Advanced Studies in Communication (GEAC - www.geac.es) and currently member of the Executive Board of ULEPICC-España (the Spanish national chapter of the Latin Union for Political Economy of Information, Communication and Culture).

\section{Enric Saperas}

Full professor of the Department of Communication Sciences and Sociology at the King Juan Carlos University (Spain), head of the Group of Advanced Studies in Communication (GEAC - www.geac.es), and Director of the Master's Degree in Applied Research in Communication. 